kvalitetsbegrepet, nettverkskartlegging, arbeid og arbeidsrådgivning for mennesker med utviklingshemning, seksualitet og sorg og tap behandlet.

Helse er neste hovedtema. I kapitlet om fysisk aktivitet introduseres for første gang ICF (International classifications of functions) - WHOs modell for samspillet mellom helse, funksjonshemning, aktivitet og deltakelse, personfaktorer og miljøfaktorer (2). Det er egne kapitler om hørselssvikt, synssvikt og oral helse og et utmerket kapittel om oppfølging hos fastlegen. Atferdsanalytisk psykoterapi i behandling av psykiske lidelser hos mennesker med lett utviklingshemning er viet et langt kapittel. Helsedelen avsluttes med et kapittel om aldring - generelt hos utviklingshemmede og spesielt hos personer med Downs syndrom. Et kapittel om epilepsi ville ha føyd seg pent inn i denne temarekken.

Tredje hovedkapittel, om rettigheter og selvbestemmelse, er godt egnet til å slå opp i både for nybegynneren og den mer erfarne. Juristen gir klare definisjoner, praktikeren gir gode eksempler. Teoretikeren filosoferer over negativ frihet og psykologen har et nyttig kapittel om hjelpemidler for forståelse, selvstendighet og deltakelse. Avtalestyring som metode er greit beskrevet. Kapitlet om tros- og livssynsfrihet til slutt passer godt inn i helheten.

Fjerde hovedkapittel er viet utfordrende atferd. Det starter med prinsipper for konfliktmekling mellom familier og hjelpeapparatet og fortsetter med utagering og selvskading - godt skrevet om to viktige emner. Hvis psykologens perspektiv hadde vært supplert med (barne)psykiaterens, ville det blitt enda bedre. Avslutningsvis kommer to kapitler om hhv. rusbruk/rusproblemer og kriminalitet.

Dette er en av flere nye bøker om utviklingshemning beregnet på samme målgruppe. Denne bokens styrke er at man har evnet å samle mye og god klinisk erfaring mellom to permer og sette denne i et kunnskapsbasert perspektiv. Det er en rød tråd i fremstillingen som samsvarer med visjonen til Stiftelsen SOR, men hovedinntrykket er ellers at redaktørene har gitt forfatterne vel frie hender. ICF som modell og individuell plan som arbeidsredskap er nevnt i flere kapitler, men kunne i en lærebok med fordel fått en mer overordnet plass og dermed bundet det hele mer sammen.

For leger i administrative stillinger tror jeg boken kan være nyttig, ikke minst på grunn av det epidemiologiske perspektivet som er godt ivaretatt i flere av kapitlene. For fastlegen gir boken oversikt over helserelaterte problemområder som er viktige for den utviklingshemmede pasienten, men som ofte gis liten plass i medisinske lærebøker.

Kjersti Ramstad

Barneklinikken

Oslo universitetssykehus, Rikshospitalet
Litteratur

1. Stiftelsen SOR. www.samordningsradet.no (4.1.2010)

2. World Health Organization. International classification of functioning, disability and health (ICF). www.who.int/entity/classifications/icf/en/ (4.1.2010).

\section{God orientering om svensk rettspsykiatri}

Strand S, Holmberg G, Söderberg E.

Den rättspsykiatriska vården

295 s, ill. Lund: Studentlitteratur, 2009.

Pris SEK 293

ISBN 978-91-44-04855-0

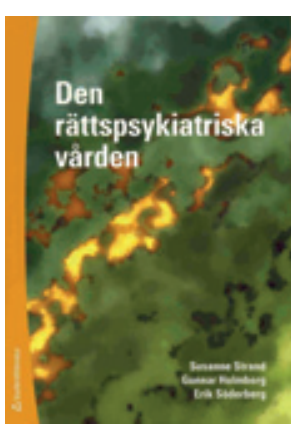

Målgruppen er hovedsakelig de som er i grunnutdanningen i det man i Sverige benevner «rättspsykiatrisk vård», noe som omfatter det vi i Norge kaller sikkerhets-, fengsels- og rettspsykiatri. Det er

ikke spesifisert hva slags personale det gjelder, men det synes å kunne være folk fra forskjellige utdanningsområder, uten og med høyskole/universitetsbakgrunn. For leger synes den å være mest aktuell som lærebok for nybegynnere i det ovennevnte feltet. Forfatterne er alle kjente personer på fagområdet i Sverige, og de utgjør samlet en betydelig kompetanse av henholdsvis klinisk, vitenskapelig, kriminologisk og administrativ/forvaltningsmessig art.

Oppbygningen er velordnet i kapitler og underkapitler som samlet gir etter anmelderens mening en full, kortfattet oversikt over feltet på de områdene som forfatterne representerer. Blant annet er sykdomsog avvikstyper i psykiatrien godt beskrevet, med aktuelle henvisninger til moderne forskning. Dette gjelder ikke minst for personlighetsforstyrrelser og risikovurderingsredskaper. Den synes lettlest på svensk også for en nordmann, med få og greie tabeller og figurer og med nøktern innbinding.

For svenske forhold synes boken å være til god nytte overfor hovedgruppen med moderat utdanning innen dette aktuelle og viktige området og som supplering for andre interesserte. For norske forhold er nytteverdien klart mindre. Dette skyldes ikke forfatternes innsats, men det at organiseringen av sikkerhets-, fengsels- og rettspsykiatrien er svært forskjellig i de to landene. Noen eksempler på dette: Ved rettspsykiatriske vurderinger før eventuell dom har ikke Sverige det grunnbegrepet som vi i Norge og mange andre land kan sammenfatte i ordet «utilregnelighet», og som er grunnlag for straffefritak. Hos oss er dette begrenset til manifeste psykotiske tilstander, til såkalt bevisstløshet og høygradig utviklingshemming, men i Sverige opererer man med begrepet «allvarlig psykisk størning», som er klart mer omfattende diagnostisk. Det er også en rekke andre forskjeller fra hos oss i oppleggene før og etter rettssak, blant annet er alle avgjørende judisielle observasjoner i Sverige utført under institusjonsinnlagt status, til stor forskjell fra her. Våre sikkerhetspsykiatriske avdelinger er en del av det psykiatriske sykehustilbudet, mens Sveriges «rättspsykiska vård» på helt annen måte er en særomsorg. Det er derfor i Norge bare aktuelt å anbefale denne gode boken som suppleringslitteratur for spesielt interesserte og ikke som sentralt læreverk.

\section{Pål Hartvig}

Kompetansesenter for sikkerhets-, fengselsog rettspsykiatri for Helseregion Sør-Øst Oslo universitetssykehus, Ullevål

\section{Ujevnt om klinisk genetikk}

\section{Paus B. \\ Klinisk genetikk}

En innføringsbok. 245 s, tab, ill. Oslo: Gyldendal Akademisk, 2009. Pris NOK 425

ISBN 978-82-05-39343-1

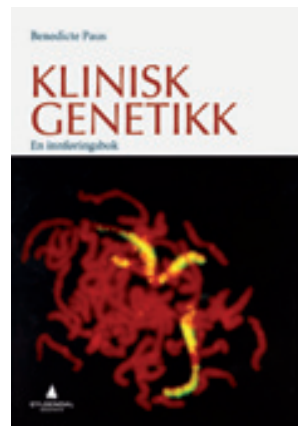

Bogen er på 245 sider og henvender sig til helsepersonale med varierende uddannelse samt er tænkt til nytte for studenter i medicin, studenter i genetisk vejledning og studenter $i$ andre helsefag samt interesserede.

Bogen er opdelt i 10 kapitler, som har stort fokus på forklaring af genetisk variation og bidrag til sygdom samt genetisk vejledning og tager herefter udvalgte områder, så som blodsygdomme, bindevævssygdomme, neuro-degenerative sygdomme, misdannelser og herefter fokus på praktisk fremgangsmåde ved genetisk diagnostik og genetisk prænatal diagnostik samt perspektiver i behandling af arvelige sygdomme.

Da bogen er på norsk og tiltænkt norsk publikum ville det have været en god idé at have et særligt kapitel om den norske bioteknologilov.

I betragtning af, at bogen kun har én forfatter, repræsenterer det en imponerende indsats fra denne. På den anden side indebærer eneforfatterskab den risiko, at bestemte områder får en relativt høj vægt uden at 